Journal of Animal and Veterinary Advances 18 (1): 24-29, 2019

ISSN: $1680-5593$

(C) Medwell Journals, 2019

\title{
Effect of Dry Period Length on the Subsequent Lactation Performance in Holstein Cows under Subtropical Conditions
}

\author{
A.M.A. Rashad, D.K. EL-Hedainy and A.E. Mahdy \\ Department of Animal Production, Faculty of Agriculture (El-Shatby), Alexandria University, \\ 22545 Alexandria, Egypt
}

\begin{abstract}
Data from 3739 records of 1431 Holstein-Friesian cows belong to large commercial dairy farm in Egypt were studied to retrospectively determine the association between length of dry period and subsequent lactation milk yield, reproduction, lifetime yield and udder health status and to find out the adequate dry period length that maximizes milk production, lifetime milk yield and improves reproductive efficiency. Dry period lengths between $\leq 35$ and $\geq 120$ days were classified into eight categories with equal intervals. Sire, parity, year and season of calving affected Dry Period Length (DPL). Total 305 days milk yields increased with increasing DPL up to 78-91 days but decreased thereafter. Days open and calving interval of the subsequent lactation tended to decrease for short dry periods. Dry period of 64-77 days had the longest length of productive life $(\mathrm{p}<0.001)$ and the largest number of complete lactations, total lifetime milk yield and lifetime daily milk yield. Negative relations between DPL with total, 305 days and lifetime milk yields $(\mathrm{p}<0.050)$ but positive $(\mathrm{p}<0.010)$ with days open were found. The dry period category of 64-77 days was adequate for the best subsequent lactation performance in Holstein cows under study.
\end{abstract}

$\underline{\text { Key words: Dry period, Holstein cow, lactation performance, DPL, negative relations, subsequent lactation }}$

\section{INTRODUCTION}

A common and general practice in dairy industry is to offer lactating cows a rest period between lactations. Traditionally, 60 days were judged as an optimal dry period for a cow to rest in order to achieve maximum milk yield in subsequent lactation (Bachman and Schairer 2003; Church et al., 2008). Dry period is important for mammary gland regeneration and for the preparation of the udder for the nearly commencing lactation (Annen et al., 2004). Optimizing the dry period length was previously based upon concerns related to milk production only but now reproductive performance and health status of the cow would be taken into consideration when making such decision (Watters et al., 2009). Possible advantages of reducing length of dry period include extra income from selling additional milk and simplified dry cow management (Grummer and Rastani, 2004) but in contrast, eliminating dry period may reduce milk yield (Pytlewski et al., 2009) and lower fertility during the subsequent lactation (Kuhn et al., 2006a, b). Gumen et al. (2005) reported similar number of days open for cows with 28 and 56 days dry periods, whereas, Watters et al. (2006) recorded fewer days open associated with shorter dry periods but extending the dry period above 70 days reduced milk yield (Kuhn et al., 2007).
Under subtropical unsophisticated dairy systems, emphasis is laid on striving for attaining high milk yield for the longest possible days in milk without taking into consideration the welfare of the lactating cows. Therefore, emphasis should be placed on dry period as secondary lactation trait and to explore its association with functional traits of lactating cows.

The objectives of the present study were to retrospectively investigate the type of association between the length of dry period and lactational milk production, reproductive performance and udder health status and lifetime milk yield during the subsequent lactation and to appraise an optimum length of dry period between 45 and 60 days for Holstein-Friesian cows raised in Egypt.

\section{MATERIALS AND METHODS}

Description of data: Total of 3872 records presenting 1466 Holstein-Friesian cows were collected between 1996 and 2010 from a commercial dairy herd, located at the newly reclaimed Nubaria Region (longitude $30.0667^{\circ}$, latitude $30.6667^{\circ}$ ) $90 \mathrm{~km}$ South West of Alexandria, Egypt. DairyCOMP 305 recording system (Valley Agricultural Software Company, California, USA) was used.

Corresponding Author: A.M.A. Rashad, Department of Animal Production, Faculty of Agriculture (El-Shatby), Alexandria University, 22545 Alexandria, Egypt 
Table 1: Distribution of dry period length categories of Holstein cows under study

\begin{tabular}{lccc}
\hline Days dry length (days) & Means (days) & Frequency & Percentage \\
\hline$\leq 35$ & 24.43 & 87 & 2.95 \\
$36-49$ & 45.11 & 571 & 19.38 \\
$50-63$ & 55.81 & 1281 & 43.47 \\
$64-77$ & 69.31 & 353 & 11.98 \\
$78-91$ & 83.77 & 189 & 6.41 \\
$92-105$ & 98.41 & 159 & 5.40 \\
$106-119$ & 112.36 & 104 & 3.53 \\
$\geq 120$ & 151.94 & 203 & 6.89 \\
\hline
\end{tabular}

Cows were fed according to the NRC (2001) requirements and were housed freely in open partly shaded yards. Milk yield was recorded weekly in a fixed test day. Artificial insemination was routinely applied using frozen-thawed semen imported from USA. A milking cow was immediately subjected to drying off process when its daily milk yield dropped below $10 \mathrm{~kg}$ of milk regardless of freshening date.

Traits and factors under study: Dry Period Length (DPL) which was the time span between cease of milking and freshening was classified into 8 categories; $\leq 35,36-49$, $50-63,64-77,78-91,92-105,106-119$ and $\geq 120$ days. Milk productive traits were Total Milk Yield (TMY, kg), 305 days Milk Yield (305MY, kg) and Lactation Length (LL, d), the reproductive traits were Calving Interval (CI, d) and Days Open (DO, d), the lifetime traits were Complete Lactation Number (CLN, No.), length of Productive Life (PL, mo), Lifetime Total milk Yield (LTY, kg) and Lifetime Daily milk Yield (LDY, kg) and mastitis score (mast. score) estimated as the percentage of months of lactation during which the cows had mastitis one or more times (Young et al., 1960). Other factors considered in this study were; sire, year and season of calving, parity and age at first calving. LDY was the total milk given by a cow throughout her life divided by her age in days. The distribution of observations on DPL is in Table 1. The largest percentage of observations was located in DPL category of $50-63(43.47 \%)$.

Statistical analysis: To study the factors affecting DPL, MIXED procedure (SAS., 2004) was used according to the following model:

$$
\mathrm{Y}_{\mathrm{ij} k \mathrm{k} \text { mno }}=\mu+\mathrm{S}_{\mathrm{i}}+\mathrm{F}_{\mathrm{j}}+\mathrm{C}_{\mathrm{k}}+\mathrm{P}_{1}+\mathrm{b}_{\mathrm{m}}(\mathrm{x}-\overline{\mathrm{X}})+\mathrm{e}_{\mathrm{ij} \mathrm{j} k \mathrm{lmn}}
$$

Where:

$\mathrm{Y}_{\mathrm{ijk} \mathrm{k} \text { nno }}=$ The DPL

$\mu \quad=$ The overall mean

$\mathrm{S}_{\mathrm{i}} \quad=$ The random effect of ith sire

$\mathrm{F}_{\mathrm{j}} \quad=$ The Fixed effect of $\mathrm{jth}$ year of calving

$\mathrm{C}_{\mathrm{k}} \quad=$ The fixed effect of $\mathrm{kth}$ season of calving

$\mathrm{P}_{1} \quad=$ The fixed effect of lth parity

$\mathrm{b}_{\mathrm{m}} \quad=$ A regression coefficient of DPL on AFC $\mathrm{x}=$ An independent continuous variate of $\mathrm{AFC}$

$\overline{\mathrm{X}} \quad=$ The respective mean

$\mathrm{e}_{\mathrm{ij \textrm {kl } m}}=$ The residual error

Also, to describe the effects of DPL on the subsequent performance of traits, the following MIXED procedure model was used:

$$
\mathrm{Y}_{\mathrm{ijklmno}}=\mu+\mathrm{S}_{\mathrm{i}}+\mathrm{F}_{\mathrm{j}}+\mathrm{C}_{\mathrm{k}}+\mathrm{P}_{1}+\mathrm{D}_{\mathrm{m}}+\mathrm{b}_{\mathrm{n}}(\mathrm{x}-\overline{\mathrm{X}})+\mathrm{e}_{\mathrm{ij} \mathrm{klmno}}
$$

Where:

$\mathrm{Y}_{\mathrm{ijklmno}}=$ An observation of each analyzed trait

$\mu \quad=$ An overall mean

$\mathrm{S}_{\mathrm{i}} \quad=$ The random effect of ith sire

$F_{j} \quad=$ The Fixed effect of $j$ th year of calving

$\mathrm{C}_{\mathrm{k}} \quad=$ The fixed effect of $\mathrm{kth}$ season of calving

$\mathrm{P}_{1} \quad=$ The fixed effect of lth parity

$\mathrm{D}_{\mathrm{m}} \quad=$ The fixed effect of $\mathrm{mth}$ DPL category

$\mathrm{b}_{\mathrm{n}} \quad=$ A regression coefficient of each trait on $\mathrm{AFC}$

$\mathrm{x}=\mathrm{An}$ independent continuous variate for $\mathrm{AFC}$

$\overline{\mathrm{X}} \quad=$ The respective mean

$\mathrm{e}_{\mathrm{ij \textrm {klm } n o}}=$ The residual error

Differences among means were tested using $\mathrm{LSD}_{0.05}$. Simple regressions and correlations between DPL and all studied traits were calculated.

\section{RESULTS AND DISCUSSION}

Factors affecting DPL: Least squares means and standard errors of factors affecting DPL are presented in Table 2. Sire affected DPL $(p<0.001)$ with a wide range of solutions from 40.25-161.83 days. DPL tended to increase ( $<0.001$ ) with advanced parities. Parity 1 had the shortest DPL (59.51 days), probably due to higher persistency of first-lactation cows (Stanton et al., 1992). Though total milk yield increased with advanced lactation, first-lactation cows tended to have higher yields towards the end of lactation which resulted in longer lactations and shorter DPL (Hossein-Zadeh and Mohit, 2013). Kuhn et al. (2007) and Hossein-Zadeh and Mohit (2013) observed that first-lactation cows had the shortest DPL and cows in parity 4 and above had the longest. Rashad (2013) reported that parity had an effect $(p<0.050)$ on DPL of Holstein cows and first parity possessed the shortest dry period.

Also, season and year of calving had effects on DPL $(p<0.05)$. Summer-calvers had the shortest DPL whereas winter-calvers had the longest. Also, Hossein-Zadeh and Mohit (2013), Rashad (2013) and Usman et al. (2012) reported effects of season of calving on DPL $(\mathrm{p}<0.010)$. DPL fluctuated by year of calving, it tended to be long before 2000 then went shorter up to 2007 (64.26 days). 
Table 2: Least Square Means (LSM) and Standard Errors (SE) of factors affecting dry period length of Holstein cows

\begin{tabular}{|c|c|c|c|}
\hline \multirow[b]{2}{*}{ Factor/level } & \multicolumn{2}{|c|}{ Dry period length (days) } & \multirow[b]{2}{*}{ p-values } \\
\hline & No. & $\mathrm{LSM} \pm \mathrm{SE}$ & \\
\hline Sire: & 361 & & \\
\hline Min. & - & $40.25 \pm 6.34^{b}$ & 0.001 \\
\hline Max. & - & $161.83 \pm 62.50^{\mathrm{a}}$ & \\
\hline \multicolumn{4}{|l|}{ Parity: } \\
\hline 1 & 1337 & $59.51 \pm 1.98^{c}$ & 0.001 \\
\hline 2 & 973 & $64.94 \pm 1.79^{b}$ & \\
\hline 3 & 639 & $65.58 \pm 1.82^{\mathrm{b}}$ & \\
\hline 4 & 387 & $74.28 \pm 2.07^{\mathrm{a}}$ & \\
\hline$\geq 5$ & 403 & $78.94 \pm 2.35^{\mathrm{a}}$ & \\
\hline \multicolumn{4}{|l|}{ Calving season: } \\
\hline Autumn & 833 & $69.94 \pm 1.65^{\mathrm{a}, \mathrm{b}}$ & 0.010 \\
\hline Winter & 1279 & $71.20 \pm 1.47^{\mathrm{a}}$ & \\
\hline Spring & 756 & $67.19 \pm 1.75^{b, c}$ & \\
\hline Summer & 871 & $66.27 \pm 1.68^{c}$ & \\
\hline \multicolumn{4}{|l|}{ Calving year: } \\
\hline 1996-1999 & 908 & $73.91 \pm 2.62^{\mathrm{a}}$ & 0.040 \\
\hline $2000-2003$ & 895 & $70.43 \pm 1.73^{\mathrm{a}}$ & \\
\hline 2004-2007 & 1133 & $64.26 \pm 2.19^{b}$ & \\
\hline $2008-2011$ & 803 & $65.99 \pm 3.26^{\mathrm{a} b}$ & \\
\hline $\begin{array}{l}\text { Regression on } \\
\text { age at first calving }\end{array}$ & & $(-0.097 \pm 0.16)^{z}$ & $0.004^{-a c}$ \\
\hline
\end{tabular}

Differences in DPL by years of calving may be attributed to changes in management practiced from time to time. Ovulation synchronizing protocols were adopted in 2004 which had lead to shorter period of days open and consequently calving interval and this eventually was reflected on DPL. Gabr (2005), Hossein-Zadeh and Mohit (2013) and Rashad (2013) obtained similar significant effects of year of calving on DPL for Friesian and Holsteins cows. The regression of DPL on AFC was negative ( $<<0.004$, Table 2$)$ but in contrast, Shalaby et al. (2001), Cilek and Tekin (2005) and Rashad (2013) reported no significant effect of AFC on DPL.

Effect of DPL on milk production performance: Non consistent trend in LL by increasing of DPL was found (Table 3), however, the longest LL was recorded for the fifth category (78-91 days) of DPL. Also, this category was associated with the highest TMY and 305MY ( $\mathrm{p}=$ 0.001 ) as compared with first category. TMY and 305MY increased with DPL up to 78-91 days and then decreased thereafter. This could be attributed to the fact that the high producing cows may need more time to restore the udder secretory tissues before the commencement of the succeeding lactation which suggests that a dry period of 78-91 days might be more adequate for that particular herd. Kuhn et al. (2006a) indicated that a dry period of 91-100 days was more satisfactory for first and second lactation cows and resulted in high milk yield. Weglarzy (2009) showed that the most advantageous DPL for milk yield was
61-90 days but Pinedo et al. (2011) recorded that a dry period of 53-76 days was associated with the highest $305 \mathrm{MY}$.

Effect of DPL on reproductive performance: DPL had no effect on reproductive traits (Table 3 ), however, DO and $\mathrm{CI}$ in the subsequent lactation had a tendency to decrease with short DPL and therefore, the increased previous DPL may lower fertility of dairy cows. This coincides with the negative association between milk yield and fertility and with the current results that DPL of 78-91 days was associated the highest TMY and 305MY and with the shortest DO and CI as compared with shorter DPL categories. Watters et al. (2009) indicated that reduction of DPL may improve cow fertility.

Effect of DPL on lifetime performance and mastitis score: Least squares means and standard errors of lifetime traits and mastitis scores in different categories of DPL are in Table 4. DPL had effects on all lifetime traits $(\mathrm{p}<0.001)$. DPL category of 64-77 days associated with the longest length of PL, CLN, LTY and LDY. The smallest DPL category of $\leq 35$ days associated with the lowest values of all lifetime traits which tended to increase with DPL up to 64-77 days then decreased thereafter.

Though the DPL of 78-91 days was the most adequate for TMY and $305 \mathrm{MY}$ that of 64-77 days was the second best for $305 \mathrm{MY}$ but was the best for lifetime performance, especially, LDY which is used as a good measure for technical sustainability. In contrast, Kuhn et al. (2006a) reported that lifetime production was maximized by $40-50$ days DPL after first lactation and by 30-40 days DPL after the second and later lactations where as DPL shorter than 30 days or longer than 70 days are costly to LTY and should be avoided.

Mastitis score was clearly affected by DPL $(\mathrm{p}=0.009)$. The DPL of 64-77 days was associated with the highest mastitis score whereas the shortest DPL exhibited the lowest score (Table 4). The high milk producing cows tended to have long lactations and are more sensitive to mastitis. In contrast, Safa et al. (2013) showed that DPL had no effect on cow health status including mastitis. Also, Watters et al. (2008) showed that shortening the dry period down to 34 days did not affect the incidence of mastitis in the subsequent lactation. Rastani et al. (2005) reported a tendency for low somatic cell score by decreasing DPL from 56-28 days and Pinedo et al. (2011) reported that extending DPL from 143-250 days was associated with increased odds of subclinical mastitis. However, short DPL had negative effect on somatic cell score (Kuhn et al., 2006b). 
Table 3: Least Squares Means (LSM) and Standard Errors (SE) of milk production and reproduction traits of Holstein cows having preceding different dry period length

\begin{tabular}{|c|c|c|c|c|c|c|}
\hline \multirow{2}{*}{$\begin{array}{l}\text { Dry period length } \\
\text { (day) }\end{array}$} & \multirow[b]{2}{*}{ No. } & \multicolumn{3}{|c|}{ Milk production traits } & \multicolumn{2}{|c|}{ Reproduction traits } \\
\hline & & $\mathrm{LL}^{\mathrm{z}}$ (days) & $\mathrm{TMY}^{\mathrm{z}}(\mathrm{kg})$ & $305 \mathrm{MY}^{\mathrm{z}}(\mathrm{kg})$ & $\mathrm{DO}^{z}$ (days) & $\mathrm{CI}^{z}$ (days) \\
\hline$\leq 35$ & 87 & $351.15 \pm 18.79$ & $4818.45 \pm 399.70^{c}$ & $3921.79 \pm 244.65^{b}$ & $187.73 \pm 20.78$ & $431.18 \pm 13.26$ \\
\hline $36-49$ & 571 & $360.20 \pm 14.17$ & $5995.12 \pm 301.44^{\mathrm{a}, \mathrm{b}}$ & $4807.41 \pm 184.51^{\mathrm{a}}$ & $203.87 \pm 15.23$ & $454.18 \pm 4.54$ \\
\hline $50-63$ & 1281 & $365.18 \pm 13.36$ & $6129.53 \pm 284.21^{\mathrm{ab}}$ & $4786.17 \pm 173.96^{\mathrm{a}}$ & $214.85 \pm 14.27$ & $460.14 \pm 3.16$ \\
\hline $64-77$ & 353 & $357.95 \pm 14.53$ & $6098.01 \pm 309.11^{\mathrm{ab}}$ & $4837.26 \pm 189.20^{\mathrm{a}}$ & $218.99 \pm 15.67$ & $462.10 \pm 6.05$ \\
\hline $78-91$ & 189 & $374.00 \pm 16.10$ & $6396.63 \pm 342.50^{\mathrm{a}}$ & $4893.26 \pm 209.63^{a}$ & $238.70 \pm 17.36$ & $466.94 \pm 8.58$ \\
\hline $106-119$ & 104 & $348.50 \pm 18.37$ & $5976.60 \pm 390.91^{\mathrm{ab}}$ & $4775.45 \pm 239.27^{\mathrm{a}}$ & $258.04 \pm 19.13$ & $464.32 \pm 12.09$ \\
\hline$\geq 120$ & 203 & $358.36 \pm 15.52$ & $5766.00 \pm 330.22^{b}$ & $4619.71 \pm 202.12^{\mathrm{a}}$ & $244.64 \pm 16.51$ & $463.53 \pm 8.82$ \\
\hline $\mathrm{p}$-values & & 0.682 & 0.001 & 0.001 & 0.614 & 0.811 \\
\hline
\end{tabular}

${ }^{\mathrm{a}-\mathrm{C}}$ Least squares means with different letters in the same column within the same trait are significantly different; ${ }^{\mathrm{z}} \mathrm{LL}$ : Lactation Length, TMY: Total Milk Yield, 305d-MY: Adjusted Milk Yield for 305 days, DO: Days Open, CI: Calving Interval

Table 4: Least Squares Means (LSM) and Standard Errors (SE) of lifetime traits and mastitis score of Holstein cows in different dry period length categories

\begin{tabular}{|c|c|c|c|c|c|c|}
\hline \multirow[b]{2}{*}{$\begin{array}{l}\text { Dry period length } \\
\text { (days) }\end{array}$} & \multirow[b]{2}{*}{ No. } & \multicolumn{4}{|l|}{ Lifetime trains } & \multirow[t]{2}{*}{ Mastitis score } \\
\hline & & $\mathrm{PL}^{\mathrm{z}}(\mathrm{mo})$ & $\mathrm{CLN}^{z}(\mathrm{No})$ & $\operatorname{LTY}^{z}(\mathrm{~kg})$ & $\mathrm{LDY}^{\mathrm{z}}(\mathrm{kg} /$ day $)$ & \\
\hline$\leq 35$ & 366 & $18.03 \pm 3.67^{\mathrm{e}}$ & $1.53 \pm 0.24^{e}$ & $7377 \pm 1982^{c}$ & $3.84 \pm 0.49^{c}$ & $-0.001 \pm 0.002^{c}$ \\
\hline $36-49$ & 123 & $47.69 \pm 4.02^{\mathrm{cd}}$ & $3.45 \pm 0.26^{c}$ & $23362 \pm 2169^{a-c}$ & $9.36 \pm 0.54^{a-c}$ & $0.003 \pm 0.002^{\mathrm{abc}}$ \\
\hline $50-63$ & 427 & $50.99 \pm 3.60^{c}$ & $3.77 \pm 0.23^{b}$ & $25699 \pm 1945^{b c}$ & $9.96 \pm 0.48^{b c}$ & $0.001 \pm 0.002^{b c}$ \\
\hline $64-77$ & 228 & $61.52 \pm 3.78^{\mathrm{a}}$ & $4.36 \pm 0.25^{a}$ & $29174 \pm 2040^{\mathrm{a}}$ & $10.22 \pm 0.50^{\mathrm{a}}$ & $0.004 \pm 0.002^{\mathrm{a}}$ \\
\hline $78-91$ & 134 & $58.49 \pm 4.10^{\mathrm{ab}}$ & $3.91 \pm 0.27^{b}$ & $26562 \pm 2214^{\mathrm{ab}}$ & $9.53 \pm 0.55^{\mathrm{ab}}$ & $0.003 \pm 0.002^{\mathrm{ab}}$ \\
\hline $92-105$ & 65 & $54.14 \pm 4.48^{b c}$ & $3.69 \pm 0.29^{b c}$ & $23357 \pm 2418^{\mathrm{a}-\mathrm{c}}$ & $8.68 \pm 0.60^{a b c}$ & $0.003 \pm 0.003^{\mathrm{abc}}$ \\
\hline $106-119$ & 43 & $49.26 \pm 4.85^{\mathrm{cd}}$ & $3.46 \pm 0.32^{b c}$ & $20767 \pm 2621^{a b c}$ & $8.23 \pm 0.65^{\mathrm{abc}}$ & $0.002 \pm 0.003^{\mathrm{abc}}$ \\
\hline$\geq 120$ & 45 & $39.56 \pm 4.94^{d}$ & $2.74 \pm 0.32^{\mathrm{d}}$ & $16701 \pm 2668^{\mathrm{abc}}$ & $7.44 \pm 0.66^{a-c}$ & $0.003 \pm 0.003^{\mathrm{abc}}$ \\
\hline $\mathrm{p}$-value & & $<0.001$ & $<0.001$ & $<0.001$ & $<0.001$ & $0.009^{a-d}$ \\
\hline
\end{tabular}

Effect of DPL on some traits as percentages in relation to category three (50-63 days): Figure 1 show the performance traits for different DPL expressed as percentages of those of group three (50-63 days) which was recommended by Atashi et al. (2013) and others as an optimum dry period (100\%). DPL of $\leq 35$ days was concomitant with the lowest percentage of $305 \mathrm{MY}$ which then tended to increase with increased the previous DPL up to 78-91 days then decreased thereafter. Also, DO tended to increase with increasing the previous DPL confirming that short dry periods may improve fertility. CLN, LTY and LDY tended to increase by similar increase in DPL up to 64-77 days then decreased thereafter. This confirms that the DPL of 64-77 could be adequate for that particular herd for its good effect on $305 \mathrm{MY}$ and lifetime performance.

Relationships between DPL and traits under study: Simple regression and correlation coefficients between DPL and different traits under study are presented in Table 5. The regression coefficients of TMY, 305MY, LTY and LDY on days dry were negative $(p<0.050)$ but those of DO and CI on DPL were positive.
Table 5: Simple regression $(\mathrm{b} \pm \mathrm{SE})$ and correlation coefficients between dry period length and different traits

\begin{tabular}{|c|c|c|c|}
\hline Traits & Intercept & $\mathrm{b} \pm \mathrm{SE}$ & $\begin{array}{l}\text { Correlation } \\
\text { coefficient }\end{array}$ \\
\hline \multicolumn{4}{|c|}{ Milk production traits: } \\
\hline $\mathrm{LL}^{\mathrm{z}}$ (days) & 383.59 & $0.04 \pm 0.07^{\mathrm{ns}}$ & $0.009^{\text {ns }}$ \\
\hline $\mathrm{TMY}^{2}(\mathrm{~kg})$ & 7904.69 & $-4.40 \pm 1.66^{*}$ & $-0.048^{* *}$ \\
\hline $305 \mathrm{MY}^{\mathrm{z}}(\mathrm{kg})$ & 6206.71 & $-5.37 \pm 1.09^{* *}$ & $-0.089^{* *}$ \\
\hline \multicolumn{4}{|c|}{ Reproductive traits: } \\
\hline $\mathrm{DO}^{\mathrm{z}}$ (days) & 170.02 & $0.24 \pm 0.08^{* *}$ & $0.095^{* *}$ \\
\hline $\mathrm{CI}^{z}$ (days) & 444.38 & $0.22 \pm 0.08^{*}$ & $0.035^{\text {ns }}$ \\
\hline \multicolumn{4}{|l|}{ Lifetime traits: } \\
\hline $\mathrm{PL}^{\mathrm{z}}(\mathrm{mo})$ & 78.93 & $0.05 \pm 0.03^{\text {ns }}$ & $0.039^{\text {ns }}$ \\
\hline $\mathrm{CLN}^{z}$ (no.) & 3.99 & $0.0001 \pm 0.0001^{\text {ns }}$ & $-0.025^{\text {ns }}$ \\
\hline $\operatorname{LTY}^{2}(\mathrm{~kg})$ & 27500 & $-35.31 \pm 16.85^{*}$ & $-0.064^{*}$ \\
\hline $\mathrm{LDY}^{\mathrm{z}}$ (kg/days) & 11.04 & $-0.02 \pm 0.0001^{* *}$ & $-0.177^{* *}$ \\
\hline Mastitis score ${ }^{z}$ & 0.01 & $0.0001 \pm 0.0001^{\mathrm{ns}}$ & $-0.025^{\text {ns }}$ \\
\hline \multicolumn{4}{|c|}{$\begin{array}{l}\text { NS: Not Significant; *Significant at } \mathrm{p}<0.05 ; * * \text { Significant at } \mathrm{p}<0.01 \text {; } \\
{ }^{\mathrm{z}} \text { LL: Lactation Length, TMY: Total Milk Yield, } 305 \text { days-MY: Adjusted } \\
\text { Milk Yield for } 305 \text { days, DO: Days Open, CI: Calving Interval, PL: } \\
\text { Productive Life Length, CLN: Complete Lactation Number, LTY: Lifetime } \\
\text { Total Milk Yield, LDY: Lifetime Daily milk Yield; Mastitis Score: } \\
\text { calculated as the percentage of months of lactation during which the cows } \\
\text { had mastitis one or more times }\end{array}$} \\
\hline
\end{tabular}

The correlations between DPL and each of TMY, 305MY, LTY and LDY were negative and confirmed the decreased in yields of milk per lactation or lifespan with the increase of DPL. The correlations between days dry 


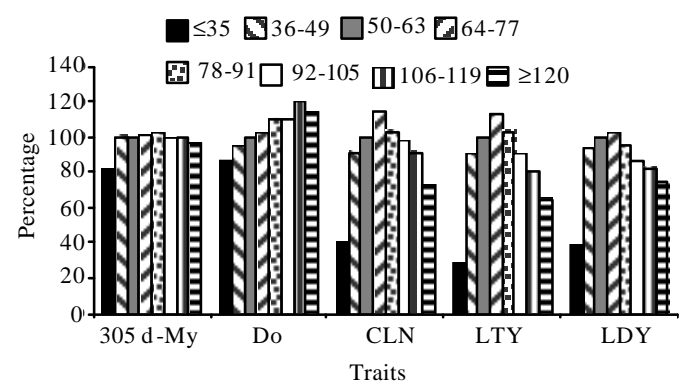

Fig. 1: Percentages of performance traits in dry period categories relative to those of 50-63 days. 305MY: Adjusted Milk Yield for 305 days, DO: Days Open, CLN: Complete Lactation Number, LTY: Lifetime Total milk Yield, LDY: Lifetime Daily milk Yield

with CLN and mastitis score were negative but not significant but were significant positive with $\mathrm{DO}$ only but not with LL, CI and PL.

Similar results were obtained by Hossein-Zadeh and Mohit (2013) for the association between DPL with TMY and CI but not by Degaris et al. (2008) who reported an increase in TMY with the increase in DPL. However, Sawa et al. (2013) found a correlation coefficient approaching zero between DPL with LL and TMY.

\section{CONCLUSION}

In conclusion, studying dry period length is very important for milk production, reproductive performance and health status of the cow. The most adequate length of dry period is 64-77 days in Holstein cows raised under subtropical conditions.

\section{ACKNOWLEDGEMENTS}

The authors wish to thank El-Alamiah Universal Company for kindly providing data. The cooperation of the company's team is greatly appreciated.

Compliance with ethical standards: All applicable international, national and/or institutional guidelines for the care and use of animals were followed. All procedures performed in studies involving animals were in accordance with the ethical standards of the institution or practice at which the studies were conducted. Also, the study was conducted in a manner that avoided unnecessary discomfort to the animals by the use of proper management.

\section{REFERENCES}

Annen, E.L., R.J. Collier, M.A. McGuire, J.L. Vicini, J.M. Ballam and M.J. Lormore, 2004. Effect of modified dry period lengths and Bovine somatotropin on yield and composition of milk from dairy cows. J. Dairy Sci., 87: 3746-3761.

Atashi, H., M.J. Zamiri and M. Dadpasand, 2013. Association between dry period length and lactation performance, lactation curve, calf birth weight, and dystocia in Holstein dairy cows in Iran. J. Dairy Sci., 96: 3632-3638.

Bachman, K.C. and M.L. Schairer, 2003. Invited review: Bovine studies on optimal lengths of dry periods. J. Dairy Sci., 86: 3027-3037.

Church, G.T., L.K. Fox, C.T. Gaskins, D.D. Hancock and J.M. Gay, 2008. The effect of a shortened dry period on intramammary infections during the subsequent lactation. J. Dairy Sci., 91: 4219-4225.

Cilek, S. and M.E. Tekin, 2005. Environmental factors affecting milk yield and fertility traits of Simmental cows raised at the Kazova State Farm and phenotypic correlations between these traits. Turk. J. Vet. Anim. Sci., 29: 987-993.

Degaris, P.J., I.J. Lean, A.R. Rabiee and C. Heuer, 2008. Effects of increasing days of exposure to prepartum transition diets on milk production and milk composition in dairy cows. Aust. Vet. J., 86: 341-351.

Gabr, A.A., 2005. Evaluation of some economic traits of Friesian cows in Egypt. MSc Thesis, Faculty of Agriculture Mansoura University, Mansoura, Egypt.

Grummer, R.R. and R.R. Rastani, 2004. Why reevaluate dry period length?. J. Dairy Sci., 87: E77-E85.

Gumen, A., R.R. Rastani, R.R. Grummer and M.C. Wiltbank, 2005. Reduced dry periods and varying prepartum diets alter postpartum ovulation and reproductive measures. J. Dairy Sci., 88: 2401-2411.

Hossein-Zadeh, N.G. and A. Mohit, 2013. Effect of dry period length on the subsequent production and reproduction in Holstein cows. Spanish J. Agric. Res., 11: 100-108.

Kuhn, M.T., J.L. Hutchison and H.D. Norman, 2006b. Dry period length to maximize production across adjacent lactations and lifetime production. J. Dairy Sci., 89: 1713-1722.

Kuhn, M.T., J.L. Hutchison and H.D. Norman, 2006a. Effects of length of dry period on yields of milk fat and protein, fertility and milk somatic cell score in the subsequent lactation of dairy cows. J. Dairy Res., 73: 154-162. 
Kuhn, M.T., J.L. Hutchison and H.D. Norman, 2007. Dry period length in US Jerseys: Characterization and effects on performance. J. Dairy Sci., 90: 2069-2081.

NRC, 2001. Nutrient Requirements of Dairy Cattle. 7th Rev. Edn., National Academy of Science, Washington, DC., USA.

Pinedo, P., C. Risco and P. Melendez, 2011. A retrospective study on the association between different lengths of the dry period and subclinical mastitis, milk yield, reproductive performance and culling in Chilean dairy cows. J. Dairy Sci., 94: 106-115.

Pytlewski, J., I. Antkowiak, R. Skrzypek and K. Kesy, 2009. The effect of dry period length on milk performance traits of black-and-white Polish Holstein-Friesian and Jersey cows. Ann. Anim. Sci., 9: 341-353.

Rashad, A.M., 2013. Evaluation of performance of some dairy herds in Egypt. Ph.D Thesis, Alexandria University, Alexandria, Egypt.

Rastani, R.R., R.R. Grummer, S.J. Bertics, A. Gumen and M.C. Wiltbank et al., 2005. Reducing dry period length to simplify feeding transition cows: Milk production, energy balance and metabolic profiles. J. Dairy Sci., 88: 1004-1014.

SAS., 2004. Statistical Analysis System Users Guide: Statistics. SAS Institute Inc., Cary, NC., USA.

Safa, S., A. Soleimani and A.H. Moussavi, 2013. Improving productive and reproductive performance of Holstein dairy cows through dry period management. Asian Australas. J. Anim. Sci., 26: 630-637.

Sawa, A., M. Bogucki and K. Siatka, 2013. Effect of the first and next calvings of cows and their milk production level on the relationship between dry period length and milk yield and its composition in the subsequent lactation. Arch. Tierzucht, 56: 934-942.
Shalaby, N.A., E.S.Z.M. Oudah and M. Abdel-Momin, 2001. Genetic analysis of some productive and reproductive traits and sire evaluation in imported and locally born friesian cattle raised in Egypt. Pak. J. Biol. Sci., 4: 893-901.

Stanton, T.L., L.R. Jones, R.W. Everett and S.D. Kachman, 1992. Estimating milk, fat and protein lactation curves with a test day model. J. Dairy Sci., 75: 1691-1700.

Usman, T., G. Guo, S.M. Suhail, S. Ahmed and L. Qiaoxiang et al., 2012. Performance traits study of Holstein Friesian cattle under subtropical conditions. J. Anim. Plant Sci., 22: 92-95.

Watters, R.D., J.N. Guenther, A.E. Brickner, R.R. Rastani, P.M. Crump, P.W. Clark and R.R. Grummer, 2008. Effects of dry period length on milk production and health of dairy cattle. J. Dairy Sci., 91: 2595-2603.

Watters, R.D., M.C. Wiltbank, J.N. Guenther, A.E. Brickner, R.R. Rastani, P.M. Fricke and R.R. Grummer, 2009. Effect of dry period length on reproduction during the subsequent lactation. $\mathrm{J}$. Dairy Sci., 92: 3081-3090.

Watters, R.D., M.C. Wiltbank, P.M. Fricke, J.N. Guenther and A.E. Kulick, 2006. Effect of dry period duration on reproductive measures during the subsequent lactation in Holstein cows. J. Anim. Sci., 84: 288-288.

Weglarzy, K., 2009. Effect of dry period length on dairy production level. Works Zootech. Mater., 67: 218-218.

Young, C.W., J.E. Legates and J.G. Lecce, 1960. Genetic and phenotypic relationships between clinical mastitis, laboratory criteria, and udder height. J. Dairy Sci., 43: 54-62. 